\title{
EFEK MODERASI KEBIJAKAN HUTANG PADA PENGARUH KEBIJAKAN DIVIDEN TERHADAP HARGA SAHAM
}

\author{
Moh. Baqir Ainun \\ moh.baqir.ainun-2018@feb.unair.ac.id \\ Mahasiswa Magister Akuntansi Universitas Airlangga
}

\begin{abstract}
This research aims to examine the effect of dividend policy on stock prices with debt policy as a moderating variable. This research uses 160 samples of manufacturing companies listed on the Indonesia Stock Exchange in the 20112015 period. The research sampling method uses purposive sampling method. Multiple linear regression analysis and moderation regression analysis were used to test the first and second hypotheses. The results showed that the dividend policy had a positive effect on stock prices. Dividend payments are a positive signal for investors, thereby increasing share prices. In addition, the debt policy is proven to moderate the effect of dividend policy on stock prices. High debt can increase uncertainty and give a negative signal to investors. Increasing dividend payments can suppress negative signals and maintain reputation and stock price stability. The results confirm the signaling theory and dividend substitution hypothesis theory. This research contributes to enrich the literature on the effect of dividend policy on stock prices with debt policy as a moderating variable, and is expected to be an input for managers to determine dividend policy and debt policy to maintain share prices on the capital market.
\end{abstract}

Key words: dividend policy; debt policy; stock price; moderation.

\begin{abstract}
ABSTRAK
Penelitian ini bertujuan untuk menguji pengaruh kebijakan dividen terhadap harga saham dengan kebijakan hutang sebagai variabel moderasi. Penelitian ini menggunakan 160 sampel perusahaan-tahun pada perusahaan manufaktur yang terdaftar pada Bursa Efek Indonesia periode 2011-2015 yang dipilih menggunakan metode purposive sampling. Analisis regresi linier berganda digunakan untuk menguji hipotesis petama, dan moderating regression analysis digunakan untuk menguji hipotesis yang kedua. Hasil penelitian ini menunjukkan bahwa kebijakan dividen berpengaruh positif terhadap harga saham perusahaan karena pembayaran dividen merupakan salah satu sinyal positif bagi investor dan pada akhirnya dapat meningkatkan harga saham. Selain itu, kebijakan hutang juga terbukti dapat memoderasi pengaruh kebijakan dividen terhadap harga saham karena hutang perusahaan yang tinggi dapat meningkatkan ketidakpastian perusahaan dan memberikan sinyal negatif bagi investor, sehingga perusahaan akan meningkatkan pembagian dividennya sebagai upaya untuk menekan sinyal negatif tersebut dan menjaga reputasi perusahaan dan stabilitas harga saham. Hasil penelitian ini mengkonfirmasi teori signaling dan teori dividend substitution hypothesis. Penelitian ini berkontribusi untuk memperkaya literatur tentang pengaruh kebijakan dividen terhadap harga saham dengan kebijakan hutang sebagai pemoderasi, dan diharapkan dapat menjadi masukan bagi manajer perusahaan untuk menentukan kebijakan dividen dan kebijakan hutangnya.
\end{abstract}

Kata kunci: kebijakan dividen; kebijakan hutang; harga saham; moderasi.

\section{PENDAHULUAN}

Nilai perusahaan merupakan pembahasan penting yang menarik bagi eksekutif bisnis dan akademisi (Hung et al., 2018), karena meningkatkan nilai perusahaan merupakan tujuan utama sebuah perusahaan
(Endraswati, 2012). Perusahaan harus mampu memaksimalkan nilai perusahaan sebagai upaya untuk bertahan dalam lingkungan bisnis yang kompetitif (Chen dan Chen, 2011). Nilai perusahaan dapat diketahui dengan harga saham perusahaan di pasar 
modal (Ayem dan Nugroho, 2016; Fajaria, 2015; Fenandar dan Raharja, 2012a; Hung et al., 2018). Penggunaan harga saham sebagai salah satu cara untuk mengukur nilai perusahaan menyebabkan harga saham menjadi faktor penting yang harus diperhatikan oleh perusahaan maupun investor (Agustina, 2014). Perusahaan harus memperhatikan harga saham yang terbentuk oleh interaksi pelaku pasar modal dengan dasar harapan pada profit perusahaan (Sendow et al., 2017). Sedangkan investor harus memperhatikan harga saham untuk mempertimbangkan apakah perusahaan memiliki potensi untuk memberikan keuntungan.

Penelitian-penelitian terdahulu telah banyak memberikan bukti tentang faktorfaktor yang dapat mempengaruhi harga saham baik faktor fundamental maupun faktor teknikal. Salah satu faktor penting yang berkaitan langsung dengan harapan investor yang pada akhirnya berpengaruh pada permintaan dan penawaran saham di pasar modal adalah kebijakan dividen yang dilakukan oleh perusahaan (Fajaria, 2015; Karpavičius, 2014; Karpavičius dan Yu, 2018).

Karpavičius dan Yu (2018) menyatakan bahwa hubungan antara kebijakan dividen dan harga saham merupakan topik yang banyak diminati para akademisi. Pada akhirnya banyak teori-teori yang bermunculan seperti teori Miller dan Modigliani, teori bird in the hand, dan teori free cash flow hypothesis. Bahkan beberapa penelitian menggunakan teori signalling sebagai dasar hubungan antara kebijakan dividen dan harga saham.

Kebijakan dividen dapat menjadi sebuah sinyal positif bagi investor bahwa perusahaan dalam kondisi baik dan mampu membagikan dividennya kepada para pemegang saham (Fajaria, 2015; Karpavičius, 2014; Karpavičius dan Yu, 2018). Selain itu, pembayaran dividen yang dilakukan oleh perusahaan akan lebih disukai oleh pemegang saham karena dividen yang dibagikan diumpamakan sebagai burung dalam genggaman tangan yang pasti keberadaannya (Gordon, 1963). Pada akhirnya, kondisi demikian dapat menyebabkan harga saham meningkat karena meningkatnya permintaan terhadap saham perusahaan itu sendiri.

Faktor lain yang memiliki pengaruh terhadap nilai perusahaan adalah kebijakan hutang yang dilakukan oleh perusahaan (Ayem dan Nugroho, 2016; Endraswati, 2012; Hidayat, 2013). Kebijakan hutang merupakan keputusan tentang seberapa besar perusahaan akan menggunakan pendanaan eksternal untuk operasi perusahaan atau bagaimana perusahaan mengatur struktur modal perusahaan. Pada situasi tertentu, kebijakan hutang dapat meningkatkan harga saham perusahaan karena hutang yang dilakukan perusahaan dianggap sebagai sebuah sinyal optimisme manajemen pada pertumbuhan perusahaan di masa depan, namun dalam kondisi lain, hutang yang tidak dikelola dengan baik dapat menyebabkan perusahaan mengalami financial distress (Ayem dan Nugroho, 2016).

Adanya hubungan antara kebijakan dividen dengan harga saham serta hubungan antara kebijakan hutang dengan harga saham seperti penelitian-penelitian yang telah dilakukan memberikan bukti bahwa baik kebijakan dividen maupun kebijakan hutang sama-sama memiliki pengaruh terhadap harga saham perusahaan (Abidin et al., 2016; Ayem dan Nugroho, 2016; Endraswati, 2012; Fajaria, 2015; Hidayat, 2013; Karpavičius, 2014; Karpavičius dan Yu, 2018). Menariknya, penelitian-penelitian terdahulu juga menemukan bukti bahwa kebijakan hutang dapat mempengaruhi kebijakan dividen perusahaan (Susanto, 2011).

Susanto (2011) menyatakan bahwa perusahaan dengan kebijakan hutang yang tinggi akan cenderung untuk membagikan dividen kepada pemegang saham. Hal ini terjadi karena meningkatnya hutang akan seiring dengan meningkatnya masalah agensi antara pemegang saham dengan pihak pemberi hutang (Jensen dan Meckling, 1976). Meningkatnya masalah agensi akan membutuhkan monitoring yang tinggi, dimana 
pembagian dividen merupakan bagian dari monitoring perusahaan itu sendiri (Susanto, 2011). Oleh karena itu, perusahaan yang memiliki hutang tinggi akan meningkatkan pembagian dividen sebagai upaya untuk menekan masalah agensi yang terjadi antara pemegang saham dan pihak pemberi hutang yang pada akhirnya akan berpengaruh pada harga saham perusahaan.

Keterkaitan antara kebijakan dividen, kebijakan hutang, dan harga saham yang telah dibuktikan oleh penelitian-penelitian terdahulu memberikan alur logis baru tentang pengaruh kebijakan dividen terhadap harga saham dan keberadaan kebijakan hutang yang mampu memoderasi pengaruh tersebut (Endraswati, 2012). Kebijakan hutang yang memiliki dampak tersendiri pada kebijakan dividen sebagai upaya untuk mengurangi masalah agensi dengan melakukan pembagian dividen sebagai monitoring perusahaan dan sinyal positif bagi investor (Susanto, 2011), tentu akan meningkatkan harga saham perusahaan (Fajaria, 2015; Karpavičius, 2014; Karpavičius dan Yu, 2018).

Penelitian-penelitian yang terdahulu berfokus pada pengaruh langsung kebijakan dividen terhadap harga saham (Fajaria, 2015; Karpavičius, 2014; Karpavičius dan Yu, 2018), pengaruh langsung kebijakan hutang terhadap kebijakan dividen (Dewi dan Sedana, 2014; Kurniawati dan Isroah, 2017; Susanto, 2011), serta pengaruh langsung kebijakan hutang terhadap harga saham (Ayem dan Nugroho, 2016; Endraswati, 2012; Hidayat, 2013). Padahal, tidak menutup kemungkinan apabila kebijakan dividen dan kebijakan hutang diinteraksikan akan memiliki pengaruh tersendiri terhadap harga saham.

Perusahaan dengan kebijakan dividen tinggi dan kebijakan hutang tinggi akan menjadi pertimbangan tersendiri bagi investor dibandingkan dengan perusahaan yang memiliki kebijakan dividen tinggi dan kebijakan hutang rendah. Pertimbangan investor pada akhirnya akan menentukan keputusan investasi, dimana keputusan inves- tasi akan berpengaruh pada permintaan dan penawaran saham, serta berdampak pada harga saham. Oleh karena itu, penelitian ini memiliki keterbaruan pada bagaimana kebijakan dividen dan kebijakan hutang berinteraksi untuk mempengaruhi harga saham.

Artikel ini bertujuan untuk menguji tentang pengaruh kebijakan dividen terhadap harga saham dengan kebijakan hutang sebagai variabel moderasi. Kebijakan hutang dihipotesiskan sebagai variabel moderasi setidaknya karena dua hal. Pertama, tingginya hutang perusahaan yang berlebihan akan memberikan sinyal negatif bagi investor, sehingga perusahaan akan berinisiatif untuk meningkatkan pembagian dividen sebagai upaya meminimalkan sinyal negatif tersebut dan menjaga stabilitas harga saham perusahaan karena investor akan berpikir bahwa perusahaan yang membagikan dividen adalah perusahaan yang berada pada kondisi baik (Fajaria, 2015; Karpavičius, 2014; Karpavičius dan Yu, 2018). Kedua, pembayaran dividen merupakan salah satu cara monitoring perusahaan dan mengurangi masalah agensi (Susanto, 2011), berkurangnya masalah agensi akan meningkatkan kepercayaan investor dan meningkatkan harga saham.

\section{TINJAUAN TEORETIS \\ Teori Agensi}

Teori agensi merupakan teori yang dicetuskan oleh Jensen dan Meckling (1976). Teori ini timbul karena adanya pemisahan tugas antara pemilik perusahaan dengan pengelola perusahaan. Teori ini mengistilahkan pemilik perusahaan sebagai principal, dan pengelola perusahaan sebagai agent. Agent berkewajiban untuk mengelola perusahaan dengan baik untuk kepentingan principal, dan memperoleh kompensasi sebagai imbalannya.

Principal dan agent merupakan dua pihak yang memiliki tujuan yang sama yaitu meningkatkan utilitas pribadi dan mengorbankan pihak lain, sehingga tidak menutup kemungkinan bahwa agent akan 
mengambil keputusan untuk kepentingan pribadi dan mengorbankan kepentingan principal.

Eisenhardt (1989) menyatakan bahwa teori agensi dibangun berdasarkan tiga asumsi yang melekat pada setiap manusia sebagai berikut: 1) Self interest. Setiap manusia akan cenderung untuk mementingkan kepentingan diri sendiri dari pada kepentingan orang lain. Agent sebagai manusia biasa tentu memiliki sifat tersebut, sehingga pada kondisi tertentu agent akan mengabaikan kepentingan principal dalam pengambilan keputusan yang dibuatnya. Dimana keputusan yang diambil akan berdasarkan pada keuntungan pribadi agent, 2) Bounded rationality. Setiap manusia memiliki kapabilitas yang terbatas sesuai dengan porsinya masing-masing. Keterbatasan yang dimaksud dalam hal ini adalah keterbatasan setiap manusia dalam membentuk persepsi di masa akan dating, 3) Risk averse. Setiap manusia akan cenderung tidak menyukai risiko dan akan berusaha untuk selalu menghindarinya.

Adapun karakteristik dari teori agensi adalah sebagai berikut (Verstegen, 2001): 1) Ketika asimetri informasi terjadi, principal dan agent akan mengungkapkan sebuah rencana untuk mengidentifikasi asimetri informasi tersebut, 2) Keputusan yang dimiliki oleh principal dan agent yang memiliki tujuan untuk memaksimalkan utilitas pribadi masing-masing merupakan fondasi dasar teori agensi. Principal akan memaksimalkan utilitas pribadinya dan mengorbankan agent, begitu juga agent yang akan memaksimalkan utilitas pribadinya dan mengorbankan kepentingan principal.

Teori ini mengenalkan masalah-masalah agensi yang timbul karena adanya pemisahaan tugas dan wewenang antara pemilik perusahaan dengan pengelola perusahaan. Masalah agensi jenis pertama atau type I adalah masalah agensi yang terjadi antara pemilik perusahaan (principal) dengan pengelola perusahaan (agent). Agent merupakan pihak yang terlibat langsung dengan perusahaan sehingga agent dianggap memiliki informasi yang lebih secara kuantitas dari pada principal, ketidak seimbangan informasi yang dimiliki oleh agent dan principal dikenal dengan istilah asimetri informasi. Kondisi ini menyebabkan agent dapat berperilaku oportunistik, dimana agent akan memanfaatkan kelebihan informasi yang dimilikinya sebagai peluang untuk mengambil keputusan demi kepentingan pribadi agent dan merugikan principal. Masalah agensi kedua atau type II adalah masalah agensi yang terjadi antara pemegang saham mayoritas dan pemegang saham minoritas (Demsetz dan Lehn, 1985; Faccio et al., 2001; Lei et al., 2013). Masalah agensi yang ketiga atau type III adalah masalah agensi yang terjadi antara shareholders dan stakeholders (Madaschi, 2010).

Masalah agensi yang terjadi pada akhirnya menimbulkan biaya-biaya agensi (agency cost). Adapaun agency cost yang dimaksud adalah sebagai berikut (Jensen dan Meckling, 1976): 1) Monitoring cost. Masalah agensi yang terjadi pada hubungan keagenan dapat diminimalisir dengan adanya monitoring yang memadai dari principal terhadap agent. Monitoring yang dilakukan diharapkan dapat menekan sifat oportunistik agent untuk bertindak di luar kepentingan principal. Monitoring yang dilakukan oleh principal akan menimbulkan biaya yang ditanggung oleh principal. Biaya ini yang kemudian disebut sebagai monitoring cost, 2) Bonding cost. Hubungan agensi yang terjadi antara principal dan agent dan adanya asimetri informasi yang terjadi, pada akhirnya menimbulkan sebuah upaya untuk menjamin bahwa setiap keputusan yang dilakukan oleh agent adalah untuk kepentingan principal. Upaya ini merupakan sebuah biaya yang disebut sebagai bonding cost, 3) Residual loss. Biaya lain yang ditimbulkan oleh masalah agensi adalah residual loss. Residual loss merupakan kondisi dimana biaya-biaya telah dikeluarkan oleh agent yang seharusnya dapat menjadi keuntungan bagi principal. Teori agensi dijadikan landasan dalam penelitian ini karena kebijakan untuk membagikan divi- 
den merupakan salah satu upaya untuk mengurangi masalah agensi antara agent dan principal. Kebijakan dividen merupakan salah satu cara untuk menunjukkan bahwa tata kelola perusahaan baik dan pada akhirnya akan mengurangi masalah agensi yang ada. Selain itu, pada saat perusahaan melakukan kebijakan hutang yang tinggi, kebijakan dividen dapat menekan masalah agensi karena kebijakan dividen juga merupakan salah satu cara untuk monitoring perusahaan (Susanto, 2011).

\section{Teori Signaling}

Manajer perusahaan akan melakukan berbagai cara untuk menunjukkan bahwa kondisi perusahaan dalam keadaan baik dan profitable. Upaya ini disebut sebagai sebuah sinyal yang dikirimkan oleh perusahaan kepada pihak eksternal (E. F. Brigham dan Houaton, 2001).

Butar (2014) menyatakan bahwa sinyal yang dikirim oleh perusahaan secara umum terbagi menjadi dua. Pertama, sinyal positif yang menunjukkan bahwa perusahaan dalam kondisi baik dan menguntungkan sehingga pasar akan merespon positif pada sinyal tersebut. Kedua, sinyal negatif yang menunjukkan bahwa perusahaan sedang berada dalam kondisi kurang menguntungkan atau ketidakpastian yang tinggi sehingga pasar akan bereaksi negatif pada sinyal tersebut. Teori sinyal berasumsi bahwa manajer yang memiliki informasi lebih banyak dari pada pemegang saham harus mendistribusikan informasi tersebut kepada pemegang saham sebagai bentuk sinyal. Informasi yang disampaikan ini pada akhirnya akan menjadi salah satu cara yang dapat mengurangi ketimpangan informasi antara pihak manajer perusahaan dengan pemegang saham (Wolk et al., 2013).

Terkait dengan penelitian ini, kebijakan dividen yang dilakukan perusahaan untuk membagikan dividen kepada pemegang saham dapat menjadi salah satu sinyal positif bagi pemegang saham bahwa perusahaan sedang berada dalam kondisi yang baik dan menguntungkan sebagai tempat berinvestasi. Sedangkan kebijakan hutang yang menyebabkan proporsi struktur modal lebih condong pada hutang akan menyebabkan ketidakpastian dan risiko financial distress sehingga dapat menjadi sinyal negatif bagi pemegang saham (Ayem dan Nugroho, 2016; Bilal dan Jamil, 2015; Farooq dan Chetioui, 2012; Hussainey et al., 2011; Karpavičius, 2014; Karpavičius dan Yu, 2018; Susanto, 2011). Pada akhirnya, respon pasar akan searah dengan sinyal yang dikirimkan oleh perusahaan.

\section{Teori Dividend Substitution Hyphothesis}

Teori dividend substitution hyphothesis merupakan sebuah teori turunan dari teori agensi. Teori ini dikemukakan oleh (La Porta et al., 2000). Berdasarkan argumen Gomes (1996) yang menyatakan bahwa dividen merupakan substitute atau pengganti dari hukum, La Porta et al. (2000) menjelaskan bahwa dividen dapat menjadi salah satu alternatif yang dapat digunakan oleh perusahaan untuk menjaga reputasi perusahaan. Pembagian dividen dapat mejadi salah satu upaya untuk mengirimkan sebuah sinyal bahwa perusahaan berada pada kondisi yang baik dan menguntungkan. Pembayaran dividen yang dilakukan diharapkan dapat membentuk citra baik di pasar modal dengan asumsi bahwa hanya perusahaan yang berada pada kondisi baik yang membagikan dividennya, sehingga pemegang saham atau investor akan menduga bahwa perusahaan tersebut dalam kondisi baik karena perusahaan membagikan dividen.

Terkait dengan penelitian ini, dalam kondisi ketidakpastian yang tinggi, perusahaan akan meningkatkan pembagian dividen sebagai upaya untuk menjaga reputasi perusahaan dan menunjukkan bahwa perusahaan seakan-akan berada dalam kondisi yang baik.

\section{Saham dan Harga Saham}

Hanafi dan Halim (2009:15) menyatakan bahwa: Saham merupakan klaim paling akhir urutannya atau haknya. Bila per- 
usahaan mengalami kebangkrutan, maka kas yang ada dipakai untuk melunasi utang terlebih dahulu, baru kemudian jika terdapat sisa, kas tersebut digunakan untuk membayar pemegang saham.

Tandelilin (2010: 81) menyatakan bahwa Saham merupakan surat bukti kepemilikan atas aset-aset perusahaan yang menerbitkan saham. Dengan memiliki saham suatu perusahaan, maka investor akan mempunyai hak terhadap pendapatan dan kekayaan perusahaan, setelah dikurangi dengan pembayaran semua kewajiban perusahaan.

Darmadji dan Fakhruddin (2012:5) menyatakan bahwa Saham (stock) merupakan tanda penyertaan atau pemilikan seseorang atau badan dalam suatu perusahaan atau perseroan terbatas. Saham berwujud selembar kertas yang menerangkan bahwa pemilik kertas tersebut adalah pemilik perusahaan yang menerbitkan surat berharga tersebut.

Selain itu, Fahmi (2015: 81) menyatakan bahwa: Saham merupakan salah satu instrument pasar modal yang paling banyak diminati oleh investor, karena mampu memberikan tingkat pengembalian yang menarik. Saham adalah kertas yang tercantum dengan jelas nilai nominal, nama perusahaan, dan diikuti dengan hak dan kewajiban yang telah dijelaskan kepada setiap pemegangnya.

Berdasarkan pengertian saham di atas maka dapat diketahui bahwa saham merupakan lembaran kertas sebagai tanda bukti bahwa seseorang telah menanamkan investasi pada perusahaan dan merupakan salah satu pemilik aset dari perusahaan tersebut.

Adapun jenis-jenis saham perusahaan dapat dibagi berdasarkan kemampuan klaim, cara peralihan, dan kinerja perdagangan (Darmadji dan Fakhruddin, 2012: 6). Berdasarkan kemampuan klaim pemegang saham apabila perusahaan dilikuidasi, saham dapat dibedakan menjadi saham biasa dan saham preferen. Saham biasa merupakan saham yang pemegangnya akan menerima pembagian aset perusahaan paling akhir apabila perusahaan dilikuidasi, namun pemegang saham biasa memiliki hak suara dalam menentukan keputusan pemilihan manajemen perusahaan. Saham preferen merupakan saham yang pemegang sahamnya akan didahulukan dalam pembagian aset perusahaan dari pada pemegang saham biasa pada saat perusahaan dilikuidasi, namun pemegang saham preferen tidak memiliki hak suara.

Berdasarkan cara peralihan saham, saham dapat dibedakan menjadi bearer stock dan registered stock. Bearer stock merupakan saham yang mana di dalam saham tersebut tidak dicantumkan nama pemiliknya, sehingga saham ini dapat dengan mudah diperjual belikan. Registered stock merupakan saham yang di dalamnya telah tercantum nama pemiliknya, sehingga apabila saham ini akan dipindah tangankan maka harus mengikuti prosedur-prosedur yang telah ditentukan.

Berdasarkan pada kinerja perdagangannya, saham dibagi menjadi blue-chip stock, income stock, growth stock-well know, speculative stock, dan counter cyclical stock. Blue-chip stock merupakan saham unggulan yang memiliki reputasi tinggi di pasar dan memiliki siklus pembayaran dividen yang stabil dan konsisten. Income stock merupakan saham biasa dari suatu entimen yang memiliki kemampuan membayar deviden lebih tinggi dari rata-rata deviden yang dibayarkan pada tahun sebelumnya. Growth stockwell known merupakan saham dari suatu perusahaan go public yang merupakan leader di industrinya dan memiliki pertumbuhan yang signifikan. Speculative stocks merupakan saham emiten yang memiliki fluktuasi nilai yang tidak pasti, saham ini memiliki risiko yang tinggi namun juga menjanjikan return yang besar sebagai imbalannya. Counter cyclical stocks merupakan saham dari perusahaan yang harga sahamnya tidak terpengaruh oleh kondisi ekonomi makro maupun kondisi bisnis. Saham jenis counter cyclical stocks biasanya merupakan saham yang dimiliki oleh pemerintah. Adapun harga saham menurut Brigham dan Houston 
(2010: 7) adalah sebagai berikut: Harga saham menentukan kekayaan pemegang saham. Maksimalisasi kekayaan pemegang saham diterjemahkan menjadi memaksimalkan harga saham perusahaan. Harga saham pada satu waktu tertentu akan bergantung pada arus kas yang diharapkan diterima di masa depan oleh investor "rata-rata" jika investor membeli saham.

Selain itu, Darmadji dan Fakhruddin (2012:102) menyatakan bahwa: Harga saham merupakan harga yang terjadi di bursa pada waktu tertentu. Harga saham bisa berubah naik maupun turun dalam hitungan waktu yang begitu cepat. Ia dapat berubah dalam hitungan menit bahkan dapat berubah dalam hitungan detik. Hal tersebut memungkinkan karena tergantung dengan permintaan dan penawaran antara pembeli saham dengan penjual saham.

Berdasarkan pengertian harga saham di atas maka dapat diketahui bahwa harga saham merupakan harga dari saham suatu perusahaan pada waktu tertentu di pasar modal yang dapat mencerminkan kekayaan dari pemegang saham itu sendiri. Adapun jenis-jenis harga saham terdiri dari harga nominal, harga perdana, harga pasar, harga pembukaan, harga penutupan, harga tertinggi, harga terendah, dan harga rata-rata (Widioatmodjo, 2012).

Harga nominal merupakan harga yang tercantum dalam sertifikat saham yang ditetapkan dalam emiten untuk menilai setiap lembar saham yang dikeluarkan. Besarnya harga nominal memberikan arti penting saham karena deviden minimal biasanya ditetapkan berdasarkan nilai nominal. Adapun harga perdana merupakan pada waktu harga saham tersebut dicatat di bursa efek. Harga saham pada pasar perdana biasanya ditetapkan oleh penjamin emisi (underwriter) dan emiten. Dengan demikian akan diketahui berapa harga saham emiten itu akan dijual kepada masyarakat biasanya untuk menentukan harga perdana.

Harga pasar merupakan harga jual dari investor yang satu dengan investor yang lain. Hal ini berbeda dengan harga perdana yang merupakan harga dari perjanjian emisi kepada investor. Harga pasar terjadi setelah saham tersebut dicatatkan di bursa dimana transaksi jual beli saham tidak lagi melibatkan emiten dari penjamin emisi. Harga pasar disebut juga sebagai harga sekunder yang dapat mewakili harga perusahaan penerbitnya. Harga pasar biasanya diumumkan setiap hari.

Harga Pembukaan merupakan harga yang diminta oleh penjual atau pembeli pada saat jam bursa dibuka. Bisa saja terjadi pada saat dimulainya hari bursa itu sudah terjadi transaksi atas suatu saham, dan harga sesuai dengan yang diminta oleh penjual dan pembeli.

Harga penutupan adalah harga yang diminta oleh penjual dan pembeli pada saat akhir hari bursa. Pada keadaan demikian, bisa saja terjadi pada saat akhir hari bursa tiba-tiba terjad transaksi atas suatu saham, karena ada kesepakatan antara penjual dan pembeli. Kalau itu yang terjadi maka harga penutupan itu telah menjadi harga pasar. Namun demikian, harga ini tetap menjadi harga penutupan pada hari bursa tersebut.

Adapun harga tertinggi merupakan harga saham tertinggi pada saat transaksi pada hari bursa, sedangkan harga terendah adalah harga terendah dari transaksi saham pada hari tersebut. Adapun harga rata-rata merupakan harga rata-rata saham yang dihitung dari harga tertinggi dan harga terendah saham pada hari tersebut.

\section{Dividen dan Kebijakan Dividen}

Dividen merupakan pendistribusian laba yang dilakukan oleh perusahaan kepada pemegang saham. Jumlah dividen untuk setiap lembar saham adalah sama. Besarnya dividen yang akan dibagikan akan tergantung pada kebijakan dividen dari masing-masing perusahaan.

Pembagian dividen terkait dengan laba yang diperoleh perusahaan yang tersedia untuk pemegang saham. Laba yang dimaksud dalam hal ini merupakan laba setelah pajak yang tertera pada laporan laba rugi perusahaan. Dalam teori keuangan, 
besarnya dana yang dibagikan sebagai dividen bukanlah sama dengan laba setelah pajak. Dana yang diperoleh dari hasil operasi selama satu periode tersebut adalah sebesar laba setelah pajak ditambah dengan penyusutan.

Adapun jenis-jenis dividen yaitu dividen tunai, dividen saham, dividen harta, dan dividen likuidasi (Kieso et al., 2014:719). Dividen tunai merupakan pembagian dividen dalam bentuk uang tunai. Tujuan dari pembagian dividen tunai adalah untuk memacu kinerja saham karena dividen tunai merupakan jenis dividen yang paling diminati pemegang saham, namun dividen tunai bisa dilaksanakan jika likuiditas perusahaan memungkinkan.

Dividen saham merupakan dividen yang dibagikan perusahaan dalam bentuk saham. Dividen saham biasanya merupakan alternatif kedua jika likuiditas perusahaan tidak memungkinkan untuk melakukan dividen tunai.

Dividen harta (property dividends) merupakan dividen yang dibagikan perusahaan dalam bentuk aset. Pada umumnya, dividen harta dibagikan dalam bentuk saham yang menandakan suatu kepemilikan dari aset perusahaan. Saham dipilih karena kemudahannya dari pada dengan membagikan dalam bentuk aset seperti bangunan dan lain sebagainya.

Dividen likuidasi merupakan pengembalian dari investasi pemegang saham bukan dari laba, namun dari modal yang merupakan hasil donasi pihak luar atau pemegang saham lain dan bukan merupakan kontribusi dari pemegang saham tertentu.

Setiap perusahaan akan mempertimbangkan apakah mereka akan membagikan dividen kepada pemegang saham atau menahannya sebagai laba ditahan. Keputusan untuk membagi dan menahan dividen ini yang kemudian disebut sebagai kebijakan dividen (Deitiana, 2011; Jahfer dan Mulafara, 2016).

Keputusan untuk membagikan atau menahan dividen merupakan salah satu keputusan yang sulit. Perusahaan yang telah membayarkan dividen akan berusaha untuk menjaga stabilitas pembayaran dividennya dan enggan untuk mengurangi pembayaran dividennya pada masa berikutnya karena khawatir pasar akan merespon negatif jika hal tersebut terjadi. Pada akhirnya, perusahaan yang telah membagikan dividen tunai akan berusaha untuk tetap melakukannya (Kieso et al., 2014: 717).

\section{Hutang dan Kebijakan Hutang}

Kieso et al. (2014: 598) menyatakan bahwa hutang merupakan kewajiban saat ini dari perusahaan yang timbul dari peristiwa masa lalu, dimana penyelesaian kewajiban tersebut diharapkan menghasilkan arus keluar dari perusahaan, yang mewujudkan manfaat ekonomi. Dengan kata lain, liabilitas memiliki tiga karakteristik penting yaitu kewajiban saat ini, disebabkan oleh peristiwa masa lalu, dan menyebabkan arus keluar dari sumber daya yang dimiliki perusahaan.

Hutang yang dimiliki perusahaan timbul berdasarkan keputusan di masa lalu yang dilakukan perusahaan untuk melakukan hutang atau tidak. Keputusan untuk melakukan dan tidak melakukan hutang ini disebut sebagai kebijakan hutang.

Adapun kebijakan hutang, Riyanto (2011:98) menyatakan bahwa: Kebijakan hutang merupakan keputusan yang sangat penting dalam perusahaan. Dimana kebijakan hutang merupakan salah satu bagian dari kebijakan pendanaan perusahaan. Kebijakan hutang adalah kebijakan yang diambil pihak manajemen dalam rangka memperoleh sumber daya pembiayaan bagi perusahaan sehingga dapat digunakan untuk membiayai aktivitas operasional perusahaan.

Berdasarkan definisi dari kebijakan hutang di atas maka dapat diketahui bahwa kebijakan hutang merupakan keputusan yang sangat penting bagi perusahaan karena akan berpengaruh terhadap kinerja perusahaan serta kelangsungan hidup perusahaan. Hutang dapat memotivasi manajemen untuk meningkatkan kinerja per- 
usahaan (Chandrarin dan Cahyaningsih, 2018; Yulianto, 2013), namun di sisi lain hutang dapat mengancam perusahaan mengalami financial distress (Ayem dan Nugroho, 2016). Oleh karena itu, kebijakan hutang yang dilakukan perusahaan harus benar-benar diperhatikan dengan baik.

\section{Pengaruh Kebijakan Dividen Terhadap Harga Saham}

Harga saham dapat menjadi salah satu tolak ukur dari nilai perusahaan. Tinggi dan rendahnya harga saham perusahaan dapat menjadi cerminan tinggi dan rendahnya nilai sebuah perusahaan (Ayem dan Nugroho, 2016; Fajaria, 2015; Fenandar dan Raharja, 2012a). Harga saham merupakan tolak ukur yang representatif untuk menggambarkan nilai perusahaan (Hung et al., 2018).

Hung et al. (2018) menyatakan bahwa memaksimalkan harga saham sama dengan memaksimalkan nilai perusahaan dan setara dengan nilai aset yang dimiliki pemegang saham, sehingga harga saham dari sebuah perusahaan merupakan tolak ukur dari nilai yang dimiliki oleh perusahaan dalam rangka memaksimalkan kesejahteraan pemilik perusahaan.

Kebijakan dividen merupakan kebijakan yang dilakukan perusahaan terkait dengan keputusan untuk membagikan dividen atau tidak (Deitiana, 2011). Kebijakan dividen merupakan hal yang penting bagi perusahaan maupun investor karena keputusan untuk membagikan dividen akan menyebabkan arus kas masuk bagi investor sebagai sumber pendapatan, sedangkan keputusan untuk menahan dividen akan menjadi sumber pendanaan bagi perusahaan (Jahfer dan Mulafara, 2016).

Kebijakan dividen selalu dianggap sebagai kebijakan pembiayaan yang penting oleh semua perusahaan karena berhubungan langsung dengan para pemangku kepentingan dan investor dan memiliki dampak yang signifikan terhadap harga pasar saham di pasar modal (Bilal dan Jamil, 2015). Dividen merupakan sebuah sinyal terhadap prospek perusahaan (Miller dan Rock, 1985), sehingga permintaan akan saham perusahaan meningkat dan pada akhirnya akan diikuti dengan harga saham yang tinggi.

Adapun teori-teori yang mendasari penelitian tentang kebijakan dividen dengan harga saham telah banyak dicetuskan oleh para ahli. Secara umum, terdapat dua teori yang bertentangan terkait hubungan antara kebijakan dividen dan harga saham (Bilal dan Jamil, 2015). Pertama, teori dividend irrelevance yang menyatakan bahwa kebijakan dividen tidak berpengaruh terhadap harga saham (Miller dan Modigliani, 1961). Kedua, Teori dividend relevance yang menyatakan bahwa kebijkan dividen dapat berpengaruh pada harga saham (Gordon, 1963). Teori lain yang juga sering digunakan dalam penelitian adalah teori signalling (Ainun, 2019; Ayem dan Nugroho, 2016; Hidayat, 2013; Nazir et al., 2010). Teori ini mengasumsikan bahwa kebijakan dividen dapat menjadi sebuah sinyal bagi investor bahwa perusahaan dalam keadaan baik dan memiliki keselarasan asumsi dengan teori dividend relevance.

Penelitian yang dilakukan oleh Bilal dan Jamil (2015) dengan menggunakan sampel perusahaan industri pada Muscat Securities Market (MSM) di Oman memberikan bukti bahwa kebijakan dividen berpengaruh positif terhadap harga saham. Farooq dan Chetioui (2012) memberikan bukti bahwa dividend payout ratio berpengaruh positif dengan nilai perusahaan dengan menggunakan sampel penelitian di MENA (Morocco, Egypt, Saudi Arabia, United Arab Emirates, Jordan, Kuwait, dan Bahrain). Penelitianpenelitian lain dengan hasil yang senada diakukan oleh Karpavičius dan Yu (2018), Karpavičius (2014), dan Hussainey et al. (2011). Pembagian dividen merupakan upaya yang dilakukan oleh perusahaan untuk mengirimkan sinyal kepada investor bahwa kondisi perusahaan dalam kondisi baik dan profitable.

Pada akhirnya sinyal positif yang dikirimkan akan memberikan dampak positif bagi nilai perusahaan dengan meningkatnya harga saham. Berdasarkan uraian di atas 
maka hipotesis pertama dalam penelitian ini adalah sebagai berikut:

$\mathrm{H}_{1}$ : Kebijakan dividen berpengaruh positif terhadap harga saham.

\section{Pengaruh Kebijakan Dividen terhadap Harga Saham dengan Kebijakan Hutang sebagai Variabel Moderasi}

Pada kondisi ketidakpastian yang tinggi, perusahaan akan cenderung membagikan dividen sebagai upaya untuk meningkatkan kepastian bagi investor dan menjaga kepercayaan investor pada perusahaan (Nazir et al., 2010). Tingkat hutang yang tinggi merupakan salah satu kondisi yang dimaksud, hal ini dikarenakan komposisi hutang yang tinggi dapat menyebabkan financial distress bagi perusahaan (Abidin et al., 2016), meskipun dalam kondisi tertentu hutang yang dimiliki perusahaan dapat menjadi sinyal bagi investor tentang optimisme perusahaan di masa depan (Ayem dan Nugroho, 2016).

Teori dividend substitution hypothesis menyatakan bahwa pembagian dividen hanya merupakan upaya untuk membangun reputasi perusahaan demi memperoleh efek positif dari pasar (La Porta et al., 2000). Pembagian dividen merupakan kamuflase untuk menutupi kondisi perusahaan yang kurang menguntungkan (Jiraporn dan Ning, 2006). Kondisi perusahaan yang kurang menguntungkan tentu akan memberikan sinyal negatif bagi investor, sehingga perusahaan akan berusaha menekan sinyal negatif tersebut dengan membagikan dividen dengan harapan investor akan ber- asumsi bahwa perusahaan masih dalam kondisi normal karena hanya perusahaan yang dalam kondisi baik yang membagikan dividennya (Ainun, 2019).

Tingginya hutang perusahaan akan mendorong perusahaan untuk berusaha agar investor tetap mempercayai perusahaan dengan cara meningkatkan pembayaran dividen sebagai salah satu cara monitoring perusahaan dan pengiriman sinyal positif bagi investor (Ainun, 2019; Ayem dan Nugroho, 2016; Hussainey et al., 2011; Jiraporn dan Ning, 2006; Karpavičius, 2014; Karpavičius dan Yu, 2018; La Porta et al., 2000; Susanto, 2011).

Perusahaan dalam kondisi normal akan membagikan dividen sebagai salah satu alat komunikasi bahwa kondisi perusahaan dalam kondisi baik, sehingga harga saham perusahaan meningkat. Namun dalam kondisi tidak pasti seperti tingginya hutang perusahaan (Abidin et al., 2016; Nazir et al., 2010), perusahaan mungkin akan semakin gencar untuk membagikan dividen sebagai upaya untuk menunjukkan bahwa perusahaan seakan-akan dalam kondisi baik dan mengembalikan reputasinya. Upaya ini diharapkan dapat menekan sinyal negatif bagi investor sehingga harga saham perusahaan tetap stabil.

Berdasarkan penjelasan di atas maka hipotesis kedua dalam penelitian ini adalah sebagai berikut:

$\mathrm{H}_{2}$ : Kebijakan hutang memoderasi pengaruh kebijakan dividen terhadap harga saham.

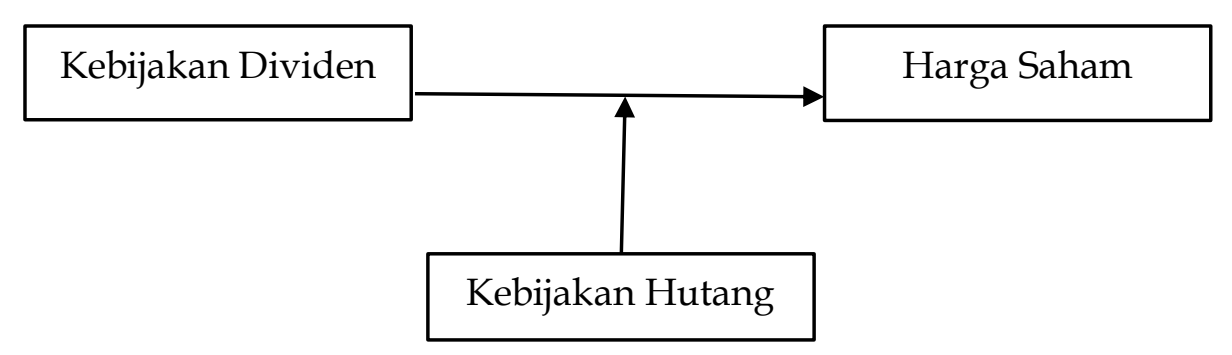

Gambar 1

Sumber: Data diolah (2019)

\section{Rerangka Pikir Penelitian}




\section{METODE PENELITIAN}

Penelitian ini merupakan penelitian kuantitatif yang berlandaskan pada filsafat positivism untuk menguji hipotesis yang telah ditetapkan sebelumnya menggunakan populasi dan sampel tertentu dan dianalisis dengan data kuantitatif dan statistik (Sugiyono, 2013: 8).

Penelitian ini menggunakan sampel 160 perusahaan-tahun pada perusahaan manufaktur yang terdaftar di Bursa Efek Indonesia periode 2011-2015. Hipotesis pertama penelitian diuji dengan menggunakan teknik analisis regresi berganda, sedangkan hipotesis kedua penelitian menggunakan teknik moderating regression analysis dengan bantuan alat statistik SPSS 25.0.

Penelitian ini menggunakan satu variabel dependen, satu variabel independen, satu variabel moderasi dan tiga variabel kontrol. Variabel dependen dalam penelitian ini adalah harga saham. Variabel independen yang digunakan adalah kebijakan dividen. Variabel moderasi dalam penelitian ini adalah kebijakan hutang yang akan diinteraksikan dengan variabel kebijakan dividen. Adapun variabel kontrol yang digunakan adalah profitabilitas, likuiditas, dan ukuran perusahaan.

Variabel kontrol digunakan dalam penelitian untuk mengurangi bias hasil pengujian dari variabel lain yang berpengaruh terhadap harga saham, namun variabel tersebut berada di luar model penelitian (de Souza et al., 2019). Penggunaan profitabilitas, likuiditas dan ukuran perusahaan dipilih sebagai variabel kontrol karena penelitianpenelitian terdahulu telah banyak memberikan bukti bahwa ketiga variabel yang dimaksud berpengaruh terhadap harga saham (Ayem dan Nugroho, 2016; Mentari, 2015; Nurhayati, 2013; Rahayu dan Dana, 2016).

Harga saham adalah harga saham suatu perusahaan yang dipengaruhi oleh aktifitas permintaan dan penawaran saham oleh pelaku pasar modal (Nababan, 2019). Adapun pengukuran harga saham dalam penelitian ini menggunakan harga saham penutupan (closing price) seperti yang telah digunakan oleh Nababan (2019) dan Deitiana (2011).

Kebijakan dividen merupakan kebijakan yang dilakukan perusahaan terkait dengan keputusan untuk membagikan dividen atau tidak (Deitian, 2011). Adapun pengukuran kebijakan dividen dalam penelitian ini menggunakan deviden payout ratio seperti yang telah digunakan oleh Odum et al. (2019), Karpavičius dan Yu (2018), Mai (2018) Bilal dan Jamil (2015), Fajaria (2015), dan Fenandar dan Raharja (2012b). Dividend payout ratio merupakan perbandingan antara dividen yang dibayarkan dengan laba bersih yang didapatkan.

$\mathrm{DPR}=\frac{\text { Dividen Perlembar Saham }}{\text { Laba Bersih Perlembar Saham }}$

Kebijakan hutang merupakan kebijakan yang dilakukan perusahaan terkait dengan besarnya hutang dalam perusahaan (Susanto, 2011). Pengukuran yang digunakan adalah Debt to Equity Ratio (DER) seperti yang digunakan oleh Uzliawati et al. (2018), dan Abidin et al. (2016). DER merupakan rasio perbandingan antara total liabilitas perusahaan dengan total ekuitas perusahaan untuk menggambarkan proporsi hutang perusahaan.

$\mathrm{DER}=\frac{\text { Total Hutang }}{\text { Total Ekuitas }}$

Adapun pengukuran yang digunakan untuk variabel kontrol profitabilitas menggunakan ratio on asset (ROA), likuiditas menggunakan current ratio (CR), dan ukuran perusahaan menggunakan log dari total aset perusahaan (Size).

$$
\begin{aligned}
& \mathrm{ROA}=\frac{E B I T}{\text { TotalAset }} \\
& \mathrm{CR}=\frac{\text { Aset Lancar }}{\text { Hutang Lancar }}
\end{aligned}
$$

Size $=L_{n}($ TotalAset $)$ 
Variabel kontrol profitabilitas digunakan dengan asumsi bahwa perusahaan yang memiliki profitabilitas tinggi akan memberikan sinyal positif bagi pasar dan pada akhirnya meningkatkan harga saham sebagai sebab dari reaksi pasar terhadap sinyal positif tersebut (Amanah, 2014; Kamilah, 2012; Octaviani dan Komalasari, 2017; Sari, 2013).

Variabel kontrol likuiditas perusahaan digunakan sebagai asumsi seberapa besar aset lancar yang dimiliki perusahaan untuk melunasi kewajiban lancarnya, termasuk untuk membayar dividen. Hal ini menjadi salah satu pertimbangan investor untuk berinvestasi, sehingga semakin tinggi likuiditas perusahaan maka semakin positif reaksi investor dan harga saham akan meningkat karena permintaan saham perusahaan naik (Clarensia et al., 2012; Rahayu dan Dana, 2016; Rompas, 2013; Wulandari, 2013).

Variabel kontrol ukuran perusahaan merupakan salah satu indikator untuk menunjukkan kemapanan sebuah perusahaan, sehingga investor akan lebih merasa aman apabila berinvestasi pada perusahaan tersebut, sehingga permintaan akan saham perusahaan meningkat dan meningkatkan harga saham (Arifin dan Agustami, 2016; Gunarso, 2014; Sofyaningsih dan Hardiningsih, 2011; Wijaya, 2017).

Sampel penelitian dalam penelitian ini adalah perusahaan manufaktur yang terdaftar di Bursa Efek Indonesia periode 20112015. Teknik pengambilan sampel menggunakan metode purposive sampling karena terbatasnya sampel yang memiliki data yang dibutuhkan dalam penelitian (Sekaran dan Bougie, 2016). Adapun kriteria penetapan sampel dalam penelitian ini adalah sebagai berikut: 1) Perusahaan Manufaktur yang terdafar di bursa efek Indonesia pada tahun 2011-2015. 2) Perusahaan yang melaksanakan pembagian dividen berturut-turut dari tahun 2011-2015. 3) Data yang tersedia lengkap untuk semua variabel penelitian.

Berdasarkan kriteria yang telah ditetapkan, jumlah sampel akhir dalam penelitian ini adalah 160 perusahaan-tahun.
Adapun teknik anlaisis data yang digunakan dalam penelitian ini adalah analisis regresi berganda untuk menguji hipotesis yang pertama, dan moderating regression analysis untuk menguji hipotesis yang kedua. Adapun model penelitian adalah sebagai berikut:

$$
\begin{aligned}
\mathrm{H}_{1}: & \text { PRICE }=\alpha+\beta 1 \mathrm{DPR}+\beta 2 \mathrm{ROA}+\beta 3 \mathrm{CR}+ \\
& \beta 4 \mathrm{SIZE}+\varepsilon \\
\mathrm{H}_{2} & : \text { PRICE }=\alpha+\beta 1 \mathrm{DPR}+\beta 2 \mathrm{DER}+ \\
& \beta 3 \mathrm{DPR}{ }^{*} \mathrm{DER}+\beta 4 \mathrm{ROA}+\beta 5 \mathrm{CR}+++ \\
& \beta 6 \mathrm{SIZE}+\varepsilon
\end{aligned}
$$

$\begin{aligned} \begin{array}{ll}\text { Keterangan: } \\ \mathrm{a}\end{array} & \text { intersep. } \\ \beta & =\begin{array}{l}\text { koefisien regresi variabel } \\ \text { independen. }\end{array} \\ \mathrm{PRICE} & \text { harga saham. } \\ \mathrm{DPR} & \text { dividen payout ratio } \\ & \text { (kebijakan diveden). } \\ \mathrm{DER} & \text { debt to equity ratio } \\ & \text { (kebijakan hutang). } \\ \mathrm{DPR} \text { DER }= & \text { Interaksi antara dividen } \\ & \text { payout ratio dan kebijakan } \\ \mathrm{ROA} & \text { hutang. } \\ \mathrm{CR} & \text { return } \\ \mathrm{CIZE} & \text { (profitabilitas). } \\ \varepsilon & \text { current ratio (likuiditas). } \\ = & \text { ukuran perusahaan. } \\ = & \text { error. }\end{aligned}$

Adapun kriteria pengujian hipotesis untuk hipotesis pertama adalah jika nilai signifikansi dibawah 0,05 maka hipotesis pertama diterima. Adapun kriteria pengujian hipotesis yang kedua dengan tingkat signifikansi $5 \%$ adalah sebagai berikut (Sekaran dan Bougie, 2016): 1) Pure moderation, apabila hubungan langsung variabel kebijakan hutang terhadap harga saham adalah tidak signifikan, sedangkan hubungan variabel kebijakan hutang yang diinteraksikan dengan kebijakan dividen berpengaruh signifikan terhadap harga saham. 2) Quasi moderation, apabila hubungan langsung variabel kebijakan hutang maupun hubungan variabel kebijakan hutang yang diinterkasikan dengan kebijakan dividen 
berpengaruh signifikan terhadap harga saham. 3) Independent predictor variable, apabila hubungan langsung variabel kebijakan hutang terhadap harga saham adalah signifikan, sedangkan hubungan variabel kebijakan hutang yang diinterkasikan dengan kebijakan dividen berpengaruh tidak signifikan terhadap harga saham.
Pada kriteria satu dan dua menunjukkan hipotesis kedua penelitian diterima, sedangkan kriteria tiga menunjukkan bahwa hipotesis kedua penelitian ditolak.

\section{ANALISIS DAN PEMBAHASAN}

Penelitian ini menggunakan analisis deskriptif untuk menggambarkan karakteristik data penelitian.

Tabel 1

Analisis Deskriptif

\begin{tabular}{lcllll}
\hline \multicolumn{5}{c}{ Descriptive Statistics } \\
\hline Log Price & N & Minimum & Maximum & Mean & Std. Deviation \\
DPR & 160 & 2,15 & 6,08 & 3,77 & 0,78 \\
DER & 160 & 0,07 & 145,92 & 42,98 & 28,04 \\
DER*DPR & 160 & 0,11 & 3,03 & 0,71 & 0,50 \\
ROA & 160 & 0,03 & 254,03 & 31,91 & 40,80 \\
CR & 160 & 0,01 & 0,66 & 0,15 & 0,10 \\
Size & 160 & 0,51 & 11,74 & 2,66 & 1,85 \\
Valid N (listwise) & 160 & 25,31 & 33,13 & 29,01 & 1,76 \\
\hline
\end{tabular}

Sumber: Data Olahan (2019)

Berdasarkan Tabel 1 dapat diketahui bahwa mean dari harga saham dalam penelitian adalah 3,77 , mean untuk DPR adalah 42,98, mean untuk DER adalah 0,71 , dan mean untuk interaksi antara DPR dan DER adalah 31,91, sedangkan mean untuk variabel kontrol ROA, CR, dan size masing-masing adalah 0.15, 2.66, dan 29.01. Selain itu, masing-masing nilai minimum dan maksimum dari harga saham adalah 2,15 dan 6,08, dari DPR adalah 0,07 dan 145,92, dari DER adalah 0,11 dan 3,03, dari interaksi antara DPR dan DER adalah 0,03 dan 254,03, dari ROA adalah 0,01 dan 0,66, dari CR sebesar 0,51 dan 11,74, dan dari size adalah 25,31 dan 33,13. Simpangan baku dalam data penelitian harga saham, DPR, DER, interaksi DPR dan DER, ROA, CR, dan size masing-masing sesebar $0,78,28,04,0,05,40,80,0,10,1,85$, dan 1,76. Adapun uji normalitas pada model 1 penelitian ini menggunakan scatter plot dengan kriteria apabila grafik PP Plots tidak menyimpang jauh dari garis diagonal maka data telah berdistribusi normal. Hasil uji normalitas ditunjukkan pada Gambar 1. Berdasarkan Gambar 1 dapat diketahui bahwa PP Plots tidak menyimpang jauh dari garis diagonal sehingga data dalam penelitian untuk model 1 adalah normal.

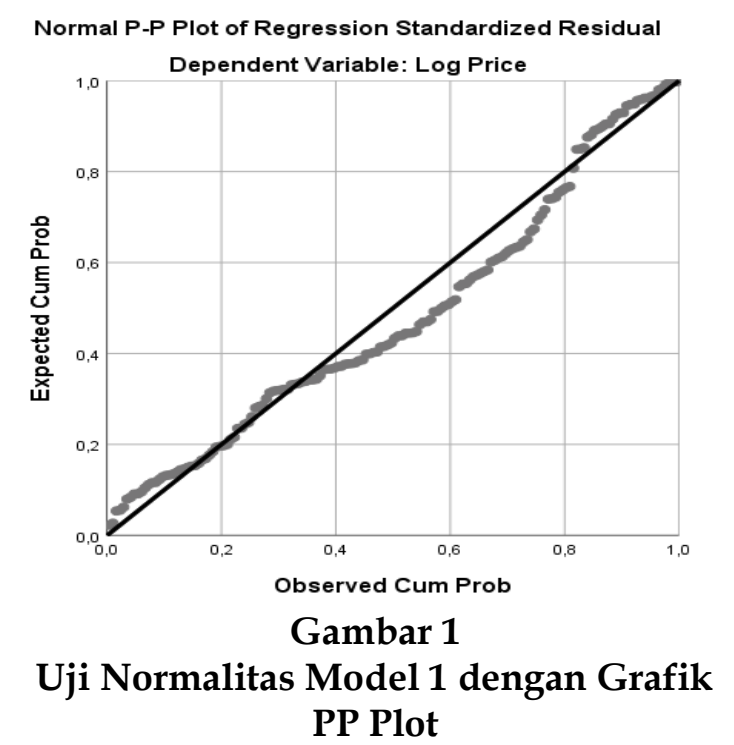

Sumber: Data Olahan (output SPSS 25 for windows) 
Tabel 2

Hasil Uji Korelasi Variabel Independen Terhadap Variabel Dependen Model 1

\begin{tabular}{lcrrr}
\hline \hline & \multicolumn{4}{c}{ Model Summary $^{\mathbf{b}}$} \\
\hline Model & $\mathrm{R}$ & R Square & Adjusted R Square & Std. Error of the Estimate \\
\hline 1 &, $719^{\mathrm{a}}$ &, 517 &, 501 &, 554024779658655 \\
\hline
\end{tabular}

a. Predictors: (Constant), Size, ROA, CR, DPR

b. Dependent Variable: Log Price

Sumber: Data Olahan (output SPSS 25 for windows)

Tabel 3

Hasil Uji F

\begin{tabular}{lrrrrr}
\hline \multicolumn{6}{c}{ ANOVA $^{\mathrm{a}}$} \\
\hline Model & Sum of Squares & df & Mean Square & F & Sig. \\
\hline 1 Regression & 50,556 & 5 & 10,111 & 32,942 &, $000^{\mathrm{b}}$ \\
Residual & 47,269 & 154 &, 307 & & \\
Total & 97,826 & 159 & & & \\
\hline
\end{tabular}

a. Dependent Variable: Log Price

b. Predictors: (Constant), Size, ROA, CR, DPR

Sumber: Data Olahan (output SPSS 25 for windows)

Adapun uji korelasi untuk model pertama dalam penelitian ini diperoleh nilai $R$ Square sebesar 0,517 seperti telah disajikan pada Tabel 2. Hal ini menunjukkan bahwa variabel independen dalam model 1 penelitian menjelaskan variabel dependennya sebesar $51,7 \%$, sedangkan sisanya dijelaskan oleh variabel lain diluar model dan error.

Selain itu, model 1 dalam penelitian ini telah dinyatakan tepat berdasarkan uji FIT dengan hasil signifikansi sebesar 0,000. Hal ini seperti telah disajikan pada Tabel 3.

Adapun uji koefisien regresi model 1 disajikan pada Tabel 4 di bawah ini.

Tabel 4

Hasil Uji Koefisien Regresi Model 1

\begin{tabular}{lllc}
\hline \multicolumn{4}{l}{ Coefficients } \\
\hline Varieble & B & T & Sig. \\
\hline (Constant) & $-1,001$ & $-1,281$ &, 000 \\
DPR &, 006 & 2,187 &, 030 \\
ROA & 4,068 & 8,328 &, 000 \\
CR &, 100 & 4,099 &, 000 \\
Size &, 147 & 5,421 &, 000
\end{tabular}

Sumber: Data Olahan (output SPSS 25 for windows)
Berdasarkan Tabel 4 di atas dapat diketahui model 1 dalam penelitian ini adalah sebagai berikut:

$$
\begin{array}{r}
\text { PRICE }=-1,281+2,187 \text { DPR }+8,328 \text { ROA } \\
+4,099 C R+5,421 \text { Size }+\varepsilon
\end{array}
$$

Model ini menunjukkan bahwa bertambahnya kebijakan dividen perusahaan (DPR) sebesar 1 akan diikuti naiknya harga saham perusahaan sebesar 2,187 dengan asumsi variabel lain dalam model penelitian adalah konstan. Dalam persamaan juga dapat diketahui bahwa apabila perusahaan tidak membagikan dividennya dengan asumsi variabel dalam penelitian adalah 0 maka saham perusahaan akan mengalami penurunan sebesar $-1,281$.

Tabel 4 juga menunjukkan bahwa DPR (kebijakan dividen) berpengaruh positif terhadap PRICE (harga saham) pada tingkat siginifikansi 5\%. Hal ini dapat dilihat dari nilai sig DPR pada uji koefisien regresi sebesar 0,030 lebih kecil dari 0,05, sehingga $\mathrm{H}_{1}$ penelitian diterima. Kebijakan dividen yang dilakukan oleh perusahaan berpengaruh positif terhadap harga saham per- 
usahaan. Semakin tinggi pembagian dividen yang dilakukan perusahaan maka harga saham akan semakin tinggi. Hal ini menunjukkan bahwa investor merespon kebijakan dividen perusahaan pada respon yang searah. Hasil penelitian ini selaras dengan hasil penelitian Karpavičius dan Yu (2018), Bilal dan Jamil (2015), Karpavičius (2014), Farooq dan Chetioui (2012), dan Hussainey et al. (2011). Hasil penelitian ini mendukung teori signaling yang mengasumsikan bahwa pembagian dividen yang dilakukan perusahaan dapat menjadi sinyal positif bagi investor. Pada akhirnya investor akan bereaksi positif terhadap pasar dan meningkatkan permintaan terhadap saham perusahaan untuk melakukan investasi pada perusahaan. Meningkatnya permintaan terhadap saham perusahaan akan menyebabkan meningkatnya harga saham perusahaan tersebut. Selanjutnya, model 2 dalam penelitian ini dilakukan uji normalitas untuk memastikan bahwa data dalam penelitian yang digunakan dalam model 2 adalah berdistribusi normal. Kriteria pengujian uji normalitas pada model 2 adalah sama dengan kriteria pengujian uji normalitas di model 1 yaitu menggunakan grafik PP Plots yang disajikan pada Gambar 2. Berdasakan Gambar 2, dapat diketahui bahwa data dalam penelitian yang digunakan untuk menguji model 2 juga telah berdistribusi normal. Hal ini bisa dilihat dari gambar PP Plots yang mengikuti garis diagonal pada Gambar 2. Adapun pengujian untuk model 2 dalam penelitian ini diperoleh nilai $R$ Square sebesar 0,532 seperti telah disajikan pada Tabel 5 . Besarnya $R$ Square pada Tabel 5 memiliki arti bahwa variabel independen pada model 2 penelitian menjelaskan variabel dependennya sebesar $53,2 \%$, sedangkan sisanya dijelaskan oleh variabel lain di luar model dan error.

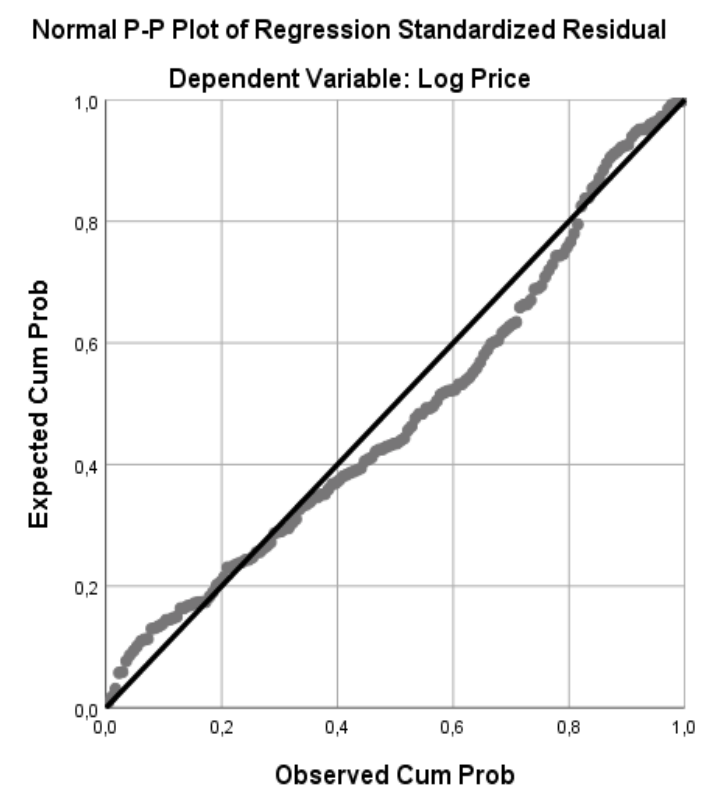

Gambar 2

Uji Normalitas Model 2 dengan Grafik PP Plot

Sumber: Data olahan (output SPSS 25 for windows)

Tabel 5

Hasil Uji Korelasi Variabel Independen Terhadap Variabel Dependen Model 2

\begin{tabular}{lcrrr}
\hline \hline & \multicolumn{3}{c}{ Model Summary $^{\mathbf{b}}$} \\
\hline Model & R & R Square & Adjusted R Square & Std. Error of the Estimate \\
\hline 1 &, $719 \mathrm{a}$ &, 532 &, 511 &, 548781518399528 \\
\hline a. Predictors: (Constant), Size, ROA, CR, DER, DPR*DER, DPR \\
b. Dependent Variable: Log Price \\
Sumber: Data Olahan (output SPSS 25 for windows)
\end{tabular}

Selain itu, uji FIT yang dilakukan terhadap model 2 penelitian diperoleh nilai sig. sebesar 0,000 yang berarti bahwa model 2 dalam penelitian adalah tepat.
Hal ini seperti disajikan pada Tabel 6. Adapun hasil uji koefisien regresi model 2 dalam penelitian ini adalah sebagai berikut pada Tabel 7. 
Tabel 6

Hasil Uji F

\begin{tabular}{|c|c|c|c|c|c|}
\hline \multicolumn{6}{|c|}{ ANOVA $^{a}$} \\
\hline Model & Sum of Squares & df & Mean Square & $\mathbf{F}$ & Sig. \\
\hline 1 Regression & 52,049 & 7 & 7,436 & 24,690 &, $000^{\mathrm{b}}$ \\
\hline Residual & 45,776 & 152 & 301 & & \\
\hline Total & 97,826 & 159 & & & \\
\hline
\end{tabular}

a. Dependent Variable: Log Price

b. Predictors: (Constant), Size, ROA, CR, Log DPR, DER, DPR*DER, DPR Sumber: Data Olahan (output SPSS 25 for windows)

Tabel 7

Hasil Uji Koefisien Regresi Model 2

\begin{tabular}{llll}
\hline \hline & \multicolumn{2}{c}{ Coefficients $^{\mathbf{a}}$} \\
\hline Variable & B & T & Sig. \\
\hline (Constant) & $-1,199$ & $-1,532$ &, 000 \\
DPR &, 010 & 2,912 &, 004 \\
DER &, 305 & 2,044 &, 043 \\
DER ${ }^{*}$ DPR &,- 005 & $-1,992$ &, 048 \\
ROA & 4,079 & 8,098 &, 000 \\
CR &, 112 & 3,626 &, 000 \\
Size &, 144 & 5,364 &, 000 \\
\hline
\end{tabular}

Sumber: Data Olahan (output SPSS 25 for windows)

Berdasarkan Tabel 7 dapat diketahui model 2 dalam penelitian ini adalah sebagai berikut:

$$
\begin{gathered}
\text { PRICE }=-1,532+2,912 D P R+2,044 \text { DER } \\
-1,992 D E R * D P R \\
+8,098 \text { ROA }+3,626 C R \\
+5,364 \text { Size }+\varepsilon
\end{gathered}
$$

Tabel 7 juga menunjukkan bahwa nilai koefisien DPR (kebijakan dividen) adalah 2,912 dengan siginifikansi 0,004 lebih kecil dari 0,05 yang menunjukkan bahwa DPR berpengaruh positif dan signifikan terhadap harga saham (PRICE).

Fokus utama pada pengujian model 2 penelitian ini adalah pada hubungan langsung dan tidak langsung kebijakan hutang (DER) terhadap harga saham (PRICE). Tabel 7 menunjukkan nilai signifikan DER sebesar 0,043 lebih kecil dari 0,05 yang berarti hubungan langsung antara kebijakan hutang dan harga saham adalah signifikan. Selain itu, nilai signifikansi kebijakan hutang yang diinteraksikan dengan kebijakan dividen (DER*DPR) adalah 0,048 lebih kecil dari 0,05 yang berarti bahwa pengaruh kebijakan hutang yang diinteraksikan dengan kebijakan dividen terhadap harga saham adalah signifikan. Berdasarkan kriteria pengujian hipotesis kedua yang telah dijelaskan pada bagian metode penelitian serta hasil uji koefisien regresi model kedua pada Tabel 7 maka dapat disimpulkan bahwa kebijakan hutang berperan sebagai quasi moderation karena baik hubungan langsung antara DER dan PRICE maupun hubungan DER yang diinteraksikan dengan DPR dan PRICE adalah sama-sama signifikan pada tingkat $5 \%$, sehingga hipotesis 2 penelitian diterima. Hasil penelitian ini mengkonfirmasi teori dividend substitution hypothesis yang menyatakan bahwa pembagian dividen merupakan upaya untuk membangun reputasi perusahaan demi memperoleh efek positif dari pasar (La Porta et al., 2000). Pembagian dividen merupakan kamuflase untuk menutupi kondisi perusahaan yang kurang baik karena tingginya hutang perusahaan (Jiraporn dan Ning, 2006). Perusahaan dalam kondisi demikian cenderung akan membagikan dividen yang lebih tinggi (Nazir et al., 2010). Kondisi perusahaan yang kurang menguntungkan tentu akan memberikan sinyal negatif bagi investor, sehingga perusahaan akan berusaha menekan sinyal negatif tersebut dengan meningkatkan pembagikan dividen dengan harapan investor akan berasumsi bahwa perusahaan masih dalam kondisi normal karena hanya per- 
usahaan yang dalam kondisi baik yang membagikan dividennya (Ainun, 2019).

Pada saat kondisi ketidakpastian perusahaan tinggi karena tingginya hutang (Nazir et al., 2010), maka perusahaan akan meningkatkan pembayaran dividen sebagai upaya untuk memberikan sinyal positif bagi investor bahwa kondisi perusahaan masih berada pada batas profitable dan aman untuk berinvesatasi. Sinyal positif dari pembagian dividen ini diharapkan dapat menekan sinyal negatif dari ketidakpastian tingginya hutang perusahaan, sehingga harga saham di pasar modal tetap stabil.

Selain itu, profitabilitas, likuiditas dan ukuran perusahaan menunjukkan pengaruh positif dan signifikan terhadap harga saham. Hasil ini menunjukkan bahwa profitabilitas perusahaan yang tinggi, likuiditas perusahaan yang tinggi, dan ukuran perusahaan yang besar dapat menjadi sinyal positif bagi investor bahwa perusahaan memiliki potensi yang menguntungkan untuk berinvestasi. Sinyal positif ini akan meningkatkan permintaan terhadap saham perusahaan, sehingga harga saham perusahaan akan naik. Hasil penelitian ini sama dengan hasil penelitian-penelitian terdahulu seperti Ayem dan Nugroho (2016), Rahayu dan Dana (2016), Mentari (2015), dan Nurhayati (2013).

Disertakannya ketiga variabel kontrol memberikan dampak pada tingkat $R$ Square yang dihasilkan. $R$ Square yang dihasilkan pada pengujian model penelitian di atas $50 \%$. $R$ Square yang semakin mendekati angka $1(100 \%)$ akan semakin bagus karena bias hasil dari variabel lain di luar model penelitian akan semakin kecil (Jr et al., 2014).

$R$ Square pada model 1 sebesar 51,7\% dan $R$ Square pada model 2 adalah $53,2 \%$. Hal ini menunjukkan bahwa ketiga variabel kontrol dapat menekan bias hasil penelitian. Ditekannya bias hasil penelitian yang dimaksud dalam penelitian ini merupakan kondisi dimana variabel lain dan error yang turut serta mempengaruhi harga saham namun tidak disertakan dalam model penelitian berada di bawah 50\% (masing- masing $48,3 \%$ dan $46,8 \%$ untuk model 1 dan model 2).

\section{SIMPULAN DAN SARAN}

Hasil penelitian ini menyimpulkan bahwa kebijakan dividen berpengaruh positif terhadap harga saham (mengkonfirmasi teori signaling) dan kebijakan hutang yang memoderasi pengaruh kebijakan dividen terhadap harga saham (mengkonfirmasi teori dividend substitution hypothesis).

Hasil penelitian berkontribusi untuk memberikan tambahan bukti empiris tentang pengaruh kebijakan dividen terhadap harga saham dan kebijakaan hutang yang dapat memoderasi pengaruh tersebut. Selain itu, hasil penelitian ini juga dapat menjadi rujukan bagi para manajer perusahaan untuk dapat menjaga nilai perusahaan dengan menjaga stabilitas harga saham di pasar modal dengan cara memperhatikan kebijakan dividen dan kebijakan hutang perusahaan.

Penelitian ini hanya menggunakan sampel dari perusahaan manufaktur serta rentang waktu yang tidak terlalu panjang, sehingga penelitian selanjutnya diharapkan dapat menambah jumlah sampel penelitian demi generalisasi hasil penelitian. Selain itu, variabel kontrol dalam penelitian ini relatif sedikit (tiga variabel kontrol), meskipun nilai $R$ Square sudah di atas $50 \%$, diharapkan penelitian selanjutnya dapat menambah variabel kontrol sebagai upaya menekan bias hasil penelitian sekecil mungkin dan mendapatkan hasil yang lebih baik.

\section{DAFTAR PUSTAKA}

Abidin, Z., Yusniar, M. W., dan Ziyad, M. 2016. Pengaruh Struktur Modal, Kebijakan Dividen dan Size terhadap Nilai Perusahaan (Studi pada Perusahaan Properti di Bursa Efek Indonesia). Jurnal Wawasan Manajemen 3(1): 91-102.

Agustina, A. 2014. Analisa Faktor-Faktor yang Mempengaruhi Pergerakan Harga Saham pada Perusahaan Pertambangan. Jurnal Wira Ekonomi Mikroskil: JWEM, 4(1): 51-60. 
Ainun, M. B. 2019. Pengaruh kebijakan dividen terhadap harga saham (studi pada perusahaan manufaktur di Bursa efek Indonesia periode 2011-2015. AKUNTABEL, 16(2): 230-237.

Amanah, R. 2014. Pengaruh rasio likuiditas dan rasio profitabilitas terhadap harga saham (Studi pada perusahaan Indeks LQ45 periode 2008-2012). Jurnal Administrasi Bisnis 12(1).

Arifin, N. F., dan Agustami, S. 2016. Pengaruh Likuiditas, Solvabilitas, Profitabilitas, Rasio Pasar, dan Ukuran Perusahaan Terhadap Harga Saham (Studi Pada Perusahaan Subsektor Perkebunan Yang Terdaftar Di Bursa Efek Indonesia Tahun 2010-2014). Jurnal Riset Akuntansi dan Keuangan 4(3): 1189-1210.

Ayem, S., dan Nugroho, R. 2016. Pengaruh Profitabilitas, Struktur Modal, Kebijakan Deviden, Dan Keputusan Investasi Terhadap Nilai Perusahaan (Studi Kasus Perusahaan Manufaktur Yang Go Publik di Bursa Efek Indonesia) Periode 20102014. Jurnal Akuntansi 4(1): 31-40.

Bilal, Z. O., dan Jamil, S. A. 2015. Does Dividend Policy Impact Stock Market Prices?-Evidence From Oman. International Journal of Applied Business and Economic Research 13(9): 6873-6883.

Brigham, dan Houston. 2010. Dasar-dasar Manajemen Keuangan Buku 1 (Edisi 11). Salemba Empat. Jakarta.

Brigham, E. F., dan Houaton, J. F. 2001. Manajemen Keuangan. Erlangga. Jakarta.

Butar, S. B. 2014. Implikasi Regulasi Pasar Modal Terhadap Motif Manajemen Laba: Pengujian Berbasis Teori Pensinyalan. Jurnal Akuntansi dan Keuangan Indonesia 11(1): 99-119.

Chandrarin, G., dan Cahyaningsih, D. S. 2018. Identifikasi Struktur Modal Melalui Profitabilitas, Pertumbuhan Penjualan dan Ukuran Perusahaan. AFRE (Accounting and Financial Review): 1(1): 36-45.

Chen, L.-J., dan Chen, S.-Y. 2011. The influence of profitability on firm value with capital structure as the mediator and firm size and industry as moderators. Investment Management and Financial Innovations 8(3): 121-129.

Clarensia, J., Rahayu, S., dan Azizah, N. 2012. Pengaruh likuiditas, profitabilitas, pertumbuhan penjualan, dan kebijakan dividen terhadap harga saham. Jurnal Akuntansi dan Keuangan 1(1): 72-88.

Darmadji, T., dan Fakhruddin. 2012. Pasar Modal Di Indonesia. Edisi. Ketiga. Salemba Empat. Jakarta.

De Souza, J. A. S., Rissatti, J. C., Rover, S., dan Borba, J. A. 2019. The linguistic complexities of narrative accounting disclosure on financial statements: An analysis based on readability characteristics. Research in International Business and Finance, 48: 59-74.

Deitiana, T. 2011. Pengaruh rasio keuangan, pertumbuhan penjualan dan dividen terhadap harga saham. Jurnal Bisnis dan Akuntansi 13(1): 57-66.

Demsetz, H., dan Lehn, K. 1985. The structure of corporate ownership: Causes and consequences. Journal of political economy 93(6): 1155-1177.

Dewi, N. W. T., dan Sedana, I. B. P. 2014. Pengaruh Struktur Modal, Likuiditas dan Pertumbuhan Terhadap Kebijakan Deviden di BEI. E-Jurnal Manajemen, 3(6): 1739-1752.

Eisenhardt, K. M. 1989. Agency Theory: An Assessment and Review. The Academy of Management Review 14(1): 57-74.

Endraswati, H. 2012. Pengaruh struktur kepemilikan dan kebijakan dividen terhadap nilai perusahaan dengan kebijakan hutang sebagai variabel moderating pada perusahaan di BEI. INFERENSI, 1-19.

Faccio, M., Lang, H., dan Young, L. 2001. Dividends and Expropriation. American Economic Review 91: 54-78.

Fahmi, I. 2015. Pengantar Manajemen Keuangan Teori dan Soal Jawab. Alfabeta. Bandung.

Fajaria, A. Z. 2015. Pengaruh Keputusan Investasi, Keputusan Pendanaan dan Kebijakan Dividen terhadap Nilai Perusahaan. 
Skripsi Sekolah Tinggi Ilmu Ekonomi Perbanas, Surabaya.

Farooq, O., dan Chetioui, Y. 2012. Corporate governance and stock price performance of firms during the crisis: evidence from the MENA region. International Journal of Business Governance and Ethics 7(4): 331349.

Fenandar, G. I., dan Raharja, S. 2012a. Pengaruh keputusan investasi, keputusan pendanaan, dan kebijakan dividen terhadap nilai perusahaan. Skripsi Fakultas Ekonomika dan Bisnis.

Fenandar, G. I., dan Raharja, S. 2012b. Pengaruh keputusan investasi, keputusan pendanaan, dan kebijakan dividen terhadap nilai perusahaan. Skripsi Universitas Diponegoro, Semarang.

Gomes, A. 1996. The dynamics of stock prices, manager ownership, and private benefits of control. Manuscript, Harvard University.

Gordon, M. J. 1963. Optimal investment and financing policy. The Journal of finance 18(2): 264-272.

Gunarso, P. 2014. Laba akuntansi, leverage, dan ukuran perusahaan terhadap harga saham di bursa efek indonesia. Jurnal Keuangan dan Perbankan 18(1): 63-71.

Hanafi, M. M., dan Halim, A. 2009. Analisis Laporan Keuangan. UPP STIM YKPN. Yogyakarta.

Hidayat, A. 2013. Pengaruh Kebijakan Hutang Dan Kebijakan Deviden Terhadap Nilai Perusahaan (Studi Empiris pada Perusahaan Manufaktur yang terdaftar di BEI). Jurnal Akuntansi 1(3).

Hung, D. N., Pham, C. D., dan Ha, V. T. B. 2018. Effects of financial statements information on firms' value: evidence from Vietnamese listed firms. Investment Management and Financial Innovations 15(4): 210-218.

Hussainey, K., Oscar Mgbame, C., dan Chijoke-Mgbame, A. M. 2011. Dividend policy and share price volatility: UK evidence. The Journal of risk finance 12(1): 57-68.
Jahfer, A., dan Mulafara, A. H. 2016. Dividend policy and share price volatility: evidence from Colombo stock market. International Journal of Managerial and Financial Accounting 8(2): 97108.

Jensen, M. C., dan Meckling, W. H. 1976. Theory of the firm: Managerial behavior, agency costs and ownership structure. Journal of financial economics 3(4): 305-360.

Jiraporn, P., dan Ning, Y. 2006. Dividend policy, shareholder rights, and corporate governance. Shareholder Rights, and Corporate Governance (September 18, 2006): 1-34.

Jr, J. F. H., Black, W. C., Babin, B. J., dan Anderson, R. E. 2014. Multivariate Data Analysis Seventh Edition. Pearson Education Limited. USA.

Kamilah, I. K. 2012. Analisis Pengaruh Rasio Profitabilitas terhadap Harga Saham pada Perusahaan Subsektor Semen yang Terdaftar di BEI. Jurnal Akuntansi UNESA 1(1): 1-19.

Karpavičius, S. 2014. Dividends: Relevance, rigidity, and signaling. Journal of Corporate Finance 25: 289-312.

Karpavičius, S., dan Yu, F. 2018. Dividend premium: Are dividend-paying stocks worth more? International Review of Financial Analysis 56: 112-126.

Kieso, D. E., Weygandt, J. J., dan Warfield, T. D. 2014. Intermediate Accounting Second Edition. United States of America: John Wiley dan Sons, Inc.

Kurniawati, S., dan Isroah, I. 2017. Pengaruh Earning Per Share, Arus Kas Kegiatan Operasi, Likuiditas dan Struktur Modal terhadap Kebijakan Dividen Tunai pada Perusahaan Go Public yang Terdaftar pada Indeks Kompas 100 Periode 20112015. Nominal, Barometer Riset Akuntansi dan Manajemen 6(2): 136-149.

La Porta, R., Lopez-de-Silanes, F., Shleifer, A., dan Vishny, R. W. 2000. Agency problems and dividend policies around the world. The Journal of finance 55(1): 133. 
Lei, Q., Lin, B., dan Wei, M. 2013. Types of agency cost, corporate governance and liquidity. Journal of Accounting and Public Policy 32(3): 147-172.

Madaschi, A. 2010. On Corporate Governance: Ownership Concentration and Firm Performance in Italy. Copenhagen Business School, Denmark.

Mai, M. U. 2018. Pengaruh Corporate Governance Mechanism Terhadap Nilai Perusahaan Melalui Pertumbuhan, Profitabilitas dan Kebijakan Dividen. Ekuitas (Jurnal Ekonomi dan Keuangan) 19(1): 42-65.

Mentari, R. I. 2015. Dampak ROE, NPM, CSR, dan Ukuran Perusahaan Terhadap Harga Saham Perusahaan yang Tercantum Dalam Indeks Lq45 Bei Periode 2010-2012. Jurnal Akuntansi, UDINUS, 117.

Miller, M. H., dan Modigliani, F. 1961. Dividend policy, growth, and the valuation of shares. The Journal of Business 34(4): 411-433.

Miller, M. H., dan Rock, K. 1985. Dividend policy under asymmetric information. The Journal of finance 40(4): 1031-1051.

Nababan, L. U. 2019. Penerapan model regresi data panel pada analisis harga saham perusahaan batubara. AKUNTABEL, 16(1): 81-97.

Nazir, M. S., Nawaz, M. M., Anwar, W., dan Ahmed, F. 2010. Determinants of stock price volatility in karachi stock exchange: The mediating role of corporate dividend policy. International Research Journal of Finance and Economics, 55(55): 100-107.

Nurhayati, M. 2013. Profitabilitas, likuiditas dan ukuran perusahaan pengaruhnya terhadap kebijakan dividen dan nilai perusahaan sektor non jasa. Jurnal Keuangan dan Bisnis Program Studi Magister Manajemen Sekolah Tinggi Ilmu Ekonomi Harapan 5(2): 144-153.

Octaviani, S., dan Komalasari, D. 2017. Pengaruh Likuiditas, Profitabilitas, dan Solvabilitas Terhadap Harga Saham.
JAK (Jurnal Akuntansi): Kajian Ilmiah Akuntansi 4(1).

Odum, A. N., Odum, C. G., Omeziri, R. I., dan Egbunike, C. F. 2019. Impact of Dividend Payout Ratio on the Value of Firm: A Study of Companies Listed on the Nigerian Stock Exchange. Indonesian Journal of Contemporary Management Research 1(1): 25-34.

Rahayu, N. M. P. S., dan Dana, I. M. 2016. Pengaruh Eva, Mva Dan Likuiditas Terhadap Harga Saham Pada Perusahaan Food And Beverages. E-Jurnal Manajemen 5(1).

Riyanto, B. 2011. Dasar-dasar Pembelanjaan Perusahaan. BPFE. Yogyakarta.

Rompas, G. P. 2013. Likuiditas Solvabilitas dan Rentabilitas Terhadap Nilai Perusahaan BUMN Yang Terdaftar Dibursa Efek Indonesia. Jurnal EMBA: Jurnal Riset Ekonomi, Manajemen, Bisnis dan Akuntansi 1(3): 252-262.

Sari, Y. 2013. Pengaruh profitabilitas, kecukupan modal dan likuiditas terhadap harga saham (perusahaan perbankan yang terdaftar di BEI). Jurnal Akuntansi, $1(1)$.

Sekaran, U., dan Bougie, R. 2016. Research Methods for Business A Skill-Building Approach Seventh Edition. United Kingdom: John Wiley dan Sons Ltd.

Sendow, G. J., Nangoi, G. B., dan Pontoh, W. 2017. Faktor-Faktor Yang Mempengaruhi Kebijakan Dividen Pada Perusahaan Manufaktur Yang Terdaftar Di Bursa Efek Indonesia Periode Tahun 20122016. Jurnal Riset Akuntansi Dan Auditing Goodwill 8(2): 317-329.

Sofyaningsih, S., dan Hardiningsih, P. 2011. Struktur kepemilikan, kebijakan dividen, kebijakan utang dan nilai perusahaan. Dinamika keuangan dan perbankan 3(1): 68-87.

Sugiyono. 2013. Metode Penelitian Pendidikan Pendekatan Kuantitatif, Kualitatif, dan $R$ dan D. Alfabeta. Bandung.

Susanto, Y. K. 2011. Kepemilikan saham, kebijakan dividen, karakteristik per- 
usahaan, risiko sistimatik, set peluang investasi dan kebijakan hutang. Jurnal Bisnis dan Akuntansi, 13(3): 195-210.

Tandelilin, E. 2010. Portofolio dan Investasi : Teori dan Aplikasi Edisi Pertama. Kanisius. Yogyakarta.

Uzliawati, L., Yuliana, A., Januarsi, Y., dan Santoso, M. 2018. Optimisation of Capital Structure and Firm Value. European Research Studies Journal 21(2): 705-713.

Verstegen, B. H. J. 2001. Nine Ways for a Decision Maker to Use Theoritical Nations with Spesial Reference to Theaching Agency Theory for Management Accounting. Journal of Accounting Eduction 19:119-127.

Widioatmodjo, S. 2012. Cara Cepat Memulai Investasi Saham Panduan Bagi Pemula. PT Elex Media Komputindo. Jakarta.
Wijaya, R. 2017. Kinerja keuangan dan ukuran perusahaan terhadap harga saham dengan kebijakan dividen sebagai variabel intervening. Jurnal Keuangan dan Perbankan 21(3): 459-472.

Wolk, H. I., Dodd, J. L., dan Rozycki, J. J. 2013. Accounting Theory Conceptual Issues in a Political and Economic Environment eighth edition. SAGE Publication, Inc. United States of America.

Wulandari, D. R. 2013. Pengaruh Profitabilitas, Operating Leverage, Likuiditas terhadap nilai perusahaan dengan struktur modal sebagai intervening. Accounting Analysis Journal 2(4).

Yulianto, A. 2013. Keputusan Struktur Modal dan Kebijakan Dividen sebagai Mekanisme Mengurangi Masalah Keagenan. Jurnal Dinamika Manajemen 4(2): 161-179. 